\title{
ВІКОВА МІНЛИВІСТЬ КАРІОТИПУ КОРІВ СІРОЇ УКРАЇНСЬКОЇ ПОРОДИ
}

\section{Л. Ф. СТАРОДУБ, Н. М. ФУРСА ${ }^{2}$}

${ }^{1}$ Інститут розведення і генетики тварин імені М.В.Зубия НААН (Чубинське, Украӥна)

'Гнститут тваринництва степових районів імені М. В. Іванова «Асканія-Нова» НААН (Асканія-Нова, Україна)

Starodublf@gmail.com

Проведено порівняльний аналіз вікової мінливості каріотипу корів сірої украӥнської породи. Встановлено підвищений у 1,5 рази рівень клітин із анеуплоїдією у телиць 9-16 місящів порівняно з коровами віком 2-2,5 роки, у яких відсоток анеуплоїдних клітин не перевищував рівень спонтанної хромосомної мінливості, характерної для великої рогатої худоби.

Ключові слова: сіра українська порода, каріотип, цитогенетичний контроль, анеуплоїдія, вікова мінливість каріотипу

\section{AGE-OLD CHANGEABILITY OF KARYOTYPE OF COWS OF GREY UKRAINIAN BREED}

L. F. Starodub ${ }^{1}$ N. M. Fursa ${ }^{2}$

${ }^{1}$ Institute of Animal Breeding and Genetics nd. a M.V.Zubets NAAS (Chubinske, Ukraine)

${ }^{2}$ Ascania Nova Institute of Animal Breeding in the Steppe Regions nd. a. M. F. Ivanov NAAS (Askania-Nova, Ukraine)

The comparative analysis of age-old changeability of karyotype of cows of the grey Ukrainian breed is conducted. An increase in 1,5 times level of cages is set with aneuploidy for heifers 916 months comparatively with cows by age 2-2,5, in that the percent of aneuploidy cages did not exceed the level of spontaneous chromosomal changeability characteristic for a cattle.

Keywords: Grey Ukrainian breed, karyotype cytogenetic control, aneuploidy, age-old changeability of karyotype

\section{ВОЗРАСТНАЯ ИЗМЕНЧИВОСТЬ КАРИОТИПА КОРОВ СЕРОЙ УКРАИНСКОЙ ПО- РОДЫ}

Л. Ф. Стародуб ${ }^{1}$, Н. Н. Фурса ${ }^{2}$

${ }^{1}$ Институт разведения и генетики животных имени М.В.Зубиа НААН (Чубинское, Украина)

${ }^{2}$ Институт животноводства степных районов имени М. В. Иванова «Аскания-Нова» НААН (Аскания-Нова, Украина)

Проведен сравнительный анализ возрастной изменчивости кариотипа коров серой украинской породы. Выявлено повышение в 1,5 раза уровня клеток с анеуплоидией у телок 9-16 месячев по сравнению с коровами возрастом 2-2,5 года, у которых прочент анеуплоидных клеток не превышал уровень спонтанной хромосомной изменчивости, характерной для крупного рогатого скота.

Ключевые слова: серая украинская порода, кариотип, цитогенетический контроль, анеуплоидия, возрастная изменчивость кариотипа

Вступ. Збереження генетичного різноманіття в тваринництві є невід'ємним елементом і повноправною складовою частиною загального процесу управління генетичними ресурсами тварин. Основною одиницею збереження біорізноманіття тваринництва є порода. За останні два десятиріччя відбулося суттєве скорочення поголів'я, яке створює реальну проблему зву- 
ження не лише породного, але і видового різноманіття сільськогосподарських тварин. Ключове поняття, що стає перед нами в проблематиці збереження генетичних ресурсів тварин - це наявність їх генетичного різноманіття як результату спадкової мінливості тварин.

На початку досліджуваного періоду достатньо високу питому вагу в усій українській популяції великої рогатої худоби мали такі аборигенні породи - білоголова та сіра українські. Проте, з 1960 року їх поголів’я почало різкими темпами знижуватися. Зараз популяції цих порід знаходяться у загрозливому стані [1]. Для кожного виду сільськогосподарських тварин визначений спектр усіх генофондових об'єктів, які передбачені для довготривалого зберігання або сталого використання із відповідною категоризацією (класифікація ФАО). Сіра українська порода великої рогатої худоби відноситься до першої категорії генофондових об'єктів та за міжнародною класифікацією - до місцевих порід [1]. Як носій рідкісних алелів, ця порода потрібна для потенційного джерела генетичного матеріалу, що може використовуватися у майбутньому [2]. Володіння інформацією про геномну нестабільність племінних тварин у ранньому віці дає змогу вести селекцію для швидкого поліпшення конкретних економічно важливих якостей.

Метою нашої роботи було встановлення співвідносності віку хромосомної нестабільності у корів сірої української породи.

Матеріали і методи досліджень. Цитогенетичний аналіз здійснювали у корів сірої української худоби (30 гол.) дослідного господарства «Маркеєво» Інституту тваринництва степових районів «Асканія-Нова».

Цитогенетичні препарати готували згідно традиційної методики [3]. Забір крові проводили із яремної вени тварини. За дві години до фіксації в культуру вводили підігрітий до $37^{\circ} \mathrm{C}$ розчин колхіцину в кінцевій концентрації 0,3-0,5 мкг/мл культурального середовища. Колхіцин затримує мітотичне ділення на стадії метафази, що дає можливість акумулювати метафазні пластинки. Для гіпотонізації використовували свіжоприготовлений $0,55 \%$-ний розчин хлористого калію $(0,28$ г на 50 мл дистильованої води). Отримані препарати після їх забарвлення аналізували на предмет хромосомної мінливості. У тварин визначали геномні мутації, пов 'язані зі зміною числа хромосом у каріотипі (відсоток метафазних пластинок із анеуплоїдією (А), асинхронне розходження центромірних районів хромосом (АРЦРХ), а також структурні порушення (хромосомні та хроматидні розриви).

У кожної тварини аналізували 100 метафазних пластинок. На цих самих препаратах підраховували кількість двоядерних лімфоцитів (ДЯ), одноядерних лімфоцитів із мікроядрами (МЯ), мітотичний індекс (МI). Частоту ДЯ, МЯ, МІ вираховували в проміле (кількість на 1000 клітин). Мікроядерний тест - показник мутаційної мінливості хромосом. Мікроядро автономно існуючий ацентричний фрагмент хромосоми, який виникає в результаті хромосомних аберацій або відставання у процесі руху клітини від анафази до телофази цілої хромосоми і розміщується у вигляді супутника біля основного ядра (рис. 1).

Частоту мікроядер (ЧМЯ) - визначали за формулою:

М - кількість мікроядер;

$$
\text { ЧМЯ }=(\mathrm{M} / \mathrm{K}) \times 1000 \text {, де }
$$

К - загальна кількість проаналізованих клітин.

Аналізувати потрібно 3000 клітин. Частота появи клітин з мікроядрами у нормі для ссавців знаходиться у межах 1,6\% [7].

Двоядерні клітини можуть виникати як компенсація дії генотоксичних агентів для підтримки генотоксичного балансу в популяціях та як наслідок старіння in vivo та in vitro i природного подовження тривалості цитокінезу. Частота двоядерних лімфоцитів і мітотичний індекс підраховується за аналогічною схемою. 


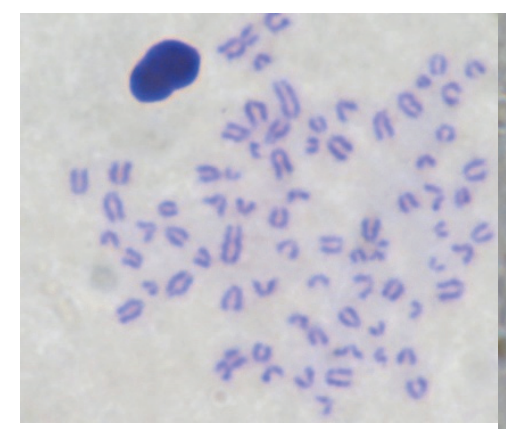

а) каріотип корови сірої української породи в нормі $(2 \mathrm{n}=60)$

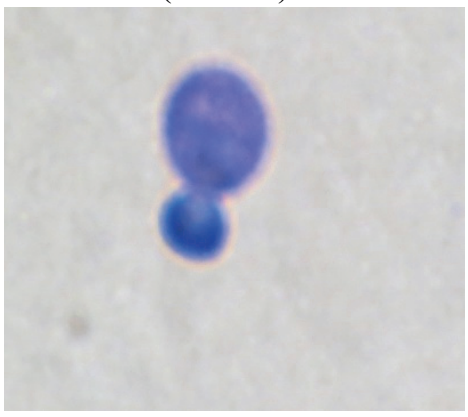

г) лімфоцит 3 мікроядром

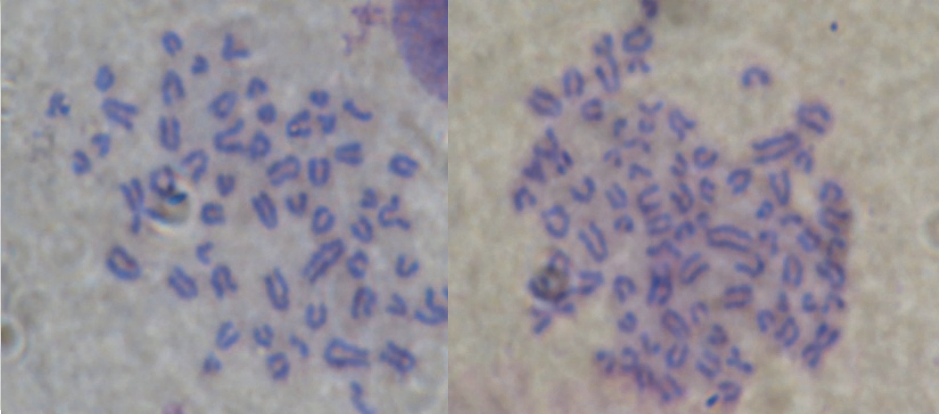

б) метафазна пластинка 3 анеуплоїдїєю $(2 \mathrm{n}=57)$

в) структурні порушення (хромосомний розрив)

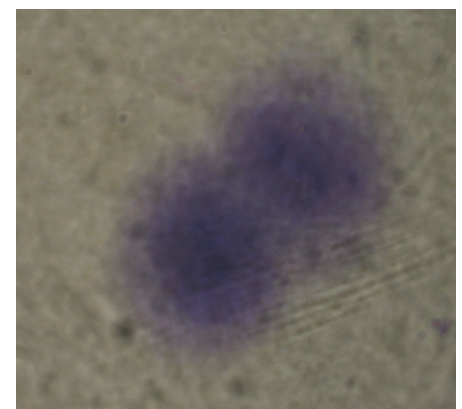

д) двоядерний лімфоцит

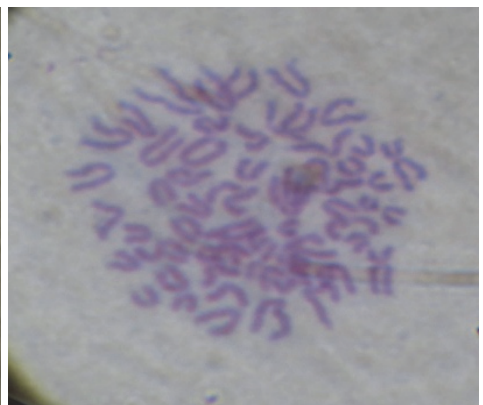

г) структурні порушення (хроматидний розрив)

Рис. 1 Цитогенетичні препарати

Результати досліджень. 3 метою встановлення співвідносності віку хромосомної нестабільності у корів сірої української породи було проведено дослідження мінливості каріотипу різновікових тварин. Для аналізу впливу віку на спонтанну мінливість каріотипу корів, яких досліджували, розділили на дві групи (телиці 9-16 місяців та корови 2-2,5 роки). Результати досліджень показані у таблиці.

Вікова мінливість каріотипу корів сірої украӥнської породи

\begin{tabular}{|c|c|c|c|c|c|c|}
\hline n гол. & Вік & $\begin{array}{c}\text { Анеуплоїдія, } \\
\%\end{array}$ & $\begin{array}{c}\text { Хромосомні } \\
\text { розриви, \% }\end{array}$ & $\begin{array}{c}\text { АРЦРХ, } \\
\%\end{array}$ & $\begin{array}{c}\text { Двоядерні } \\
\text { лімфоцити, \%о }\end{array}$ & $\begin{array}{c}\text { Лімфоцити } \\
\text { із мікроядром, \% }\end{array}$ \\
\hline 15 & $9-16$ міс. & $10,4 \pm 1,50$ & $2,6 \pm 0,86$ & $1,1 \pm 0,24$ & $2,6 \pm 0,32$ & $3,4 \pm 0,14$ \\
\hline 15 & $2-2,5$ p. & $1,3 \pm 0,62$ & $1,5 \pm 0,36$ & - & $1,8 \pm 0,42$ & $3,2 \pm 0,20$ \\
\hline
\end{tabular}

Одержані результати цитогенетичного аналізу показали, що для досліджуваних тварин характерні структурні та кількісні порушення хромосом. У телиць 9-16 міс. частка клітин із анеуплоїдією дорівнювала $10,4 \%$ - це 1,5 рази вище за спонтанний рівень $(1,5-8,3 \%)$ цієї мінливості, а у корів віком 2-2,5 роки відсоток анеуплоїдних клітин становив 1,3\% і не перевищував рівень спонтанної хромосомної мінливості, характерної для великої рогатої худоби [4]. Різниця середніх величин за цією ознакою виявилася статистично достовірною при $\mathrm{P}>0,999$. На нашу думку підвищений рівень анеуплоїдії у молодих тварин є загальнофізіологічною закономірністю [5]. Дослідниками встановлено вплив віку на спонтанну частоту хромосомної нестабільності у лімфоцитах периферійної крові ссавців. Вікова динаміка частоти анеуплоїдних наборів хромосом у людей характерна для особин старечого віку та дітей [5]. Структурні порушення хромосом (хромосомні розриви) спостерігалися у телиць 3 частотою $2,6 \%$ та у корів 1,5\%, що не перевищували межі спонтанної хромосомної мінливості $(0,17-11,1 \%)$, характерні для великої рогатої худоби. Різниця середніх величин за цією ознакою у тварин двох вікових груп була статистично недостовірна. Асинхронне розходження центромірних районів хромосом проявилося лише у телиць із частотою $1,1 \%$, i не перевищувало параметри цієї мінливості (1,5-3,7\%о) за спонтанного мутагенезу. Частка двоядерних лімфоцитів та лімфоцитів із мікроядром у клітинах периферійної крові досліджених тварин становила 1,8-2,6\%о та 3,2- 
3,4\% відповідно та відповідала спонтанному рівню цитогенетичної мінливості у розрізі їх видової належності $[6,7]$.

Висновки. У телиць 9-16 міс. сірої української породи частка клітин із анеуплоїдією дорівнювала $10,4 \%$, це 1,5 рази вище за спонтанний рівень $(1,5-8,3 \%)$ цієї мінливості, а у корів віком 2-2,5 роки відсоток анеуплоїдних клітин становив $1,3 \%$ і не перевищував рівень спонтанної хромосомної мінливості, характерної для великої рогатої худоби. На нашу думку, підвищений рівень анеуплоїдії у молодих тварин є загальнофізіологічною закономірністю. Інші показники хромосомної мінливості відносно віку тварин виявлені не були.

\section{БІБЛІОГРАФІЯ}

1. Гузєв, І. В. Методологія збереження біорізноманіття генетичних ресурсів тваринництва України : дис. ... д-ра с.-г. наук / І. В. Гузєв. - Чубинське. - 2012. - 627 с.

2. Козир, В. С. Сіра українська порода: національне надбання на межі зникнення / В. С. Козир // Агробізнес сьогодні. - 2015. - № 22 (317). - С. 3.

3. Шельов, А. В. Методика приготування метафазних хромосом лімфоцитів периферійної крові тварин / А. В. Шельов, В. В. Дзіцюк. - К. : Аграрна наука. - 2005. - 240 с.

4. Визначення генетичних аномалій у великої рогатої худоби: метод. рек. / М. І. Бащенко, К. В. Копилов, М. Л. Добрянська, Л. Ф. Стародуб, Ю. В. Подоба, К. В. Копилова. - Чубинське. $-2011 .-35$ с.

5. Кузнецов А. И. Возрастно-половая зависимость спонтанной частоты хромосомных аберраций в лимфоцитах периферической крови человека / А. И. Кузнецов, А. И. Кружалов, В. Г. Илющенко // Генетика. - 1980. - № 7. - С. 1279-1293.

6. Стародуб, Л. Ф. Цитогенетичний контроль у м'ясному і молочному скотарстві : автореф. дис. ... канд. с.-г. наук / Л. Ф. Стародуб. - Чубинське, 2011. - 20 с.

7. Джус, П. П. Видоспецифічність дестабілізації каріотипів сільськогосподарських тварин за радіаційного та інфекційного впливу : автореф. дис. ... канд. біол. наук / П. П. Джус. - К., 2012. $-20 \mathrm{c}$.

\section{REFERENCES}

1. Huziev, I. V. 2012. Metodolohiia zberezhennia bioriznomanittia henetychnykh resursiv tvarynnytstva Ukrainy - Methodology of maintenance of biovariety of genetic resources of stockraising of Ukraine : dys. ... d-ra s.-h. nauk. Chubynske, 627 (in Ukrainian).

2. Kozir, V. S. 2015. Sira ukrainska poroda: natsionalne nadbannia na mezhi znyknennia - Grey Ukrainian breed: national acquisition on verge of disappearance. Ahrobiznes sohodni - Agribusiness today. 22(317):3 (in Ukrainian).

3. Shelov, A. V. and V. V. Dzicyuk. 2005. Metodyka pryhotuvannia metafaznykh khromosom limfotsytiv peryferiinoi krovi tvaryn - Methods of preparation of metaphase chromosomes of peripheral blood lymphocytes of animals. Kyiv, Ahrarna nauka, 240 (in Ukrainian).

4. Bashhenko, M. I., K. V. Kopylov, M. L. Dobryanska, L. F. Starodub, Yu. V. Podoba, and K. V. Kopylova. 2011. Vyznachennia henetychnykh anomalii u velykoi rohatoi khudoby: metodychni rekomendatsii. - A cattle has determination of genetic anomalies. - Chubynske, 35 (in Ukrainian).

5. Kuznetsov, A. I., A. I. Kruzhalov, V. G. Ilyuschenko. 1980. Vozrastno-polovaya zavisimost spontannoy chastotyi hromosomnyih aberratsiy v limfotsitah perifericheskoy krovi cheloveka - The sexual dependence of spontaneous frequency of chromosomal aberrations age-related - is in lymphocytes of peripheral blood of man. Genetics - Genetics. 7:1279-1293(in Ukrainian).

6. Starodub, L. F. 2011. Tsitogenetichniy kontrol u myasnomu i molochnomu skotarstvi - Cytogenetic control in beef and dairy cattle breeding : dys. ... kand. s.-h. nauk. Chubynske, 20 (in Ukrainian).

7. Dshus, P. P. 2012. Vydospetsyfichnist destabilizatsii kariotypiv silskohospodarskykh tvaryn za radiatsiinoho ta infektsiinoho vplyvu - Species-specific destabilization of karyotypes of farm animals for radiation and infectious effects : avtoref. dys. ... kand. biol. nauk. Chubynske, 20 (in Ukrainian). 